\title{
Fertility of boar spermatozoa after freezing in the absence of seminal vesicular proteins
}

\author{
H. D. M. Moore* and K. G. Hibbitt \\ Institute for Research on Animal Diseases, Compton, Newbury, Berkshire, U.K.
}

Because exposure to seminal plasma enhances the detrimental effects of cold shock on boar spermatozoa (Lasley \& Bogart, 1944; Pursel, Johnson \& Rampacek, 1972), many procedures for preserving semen by deep freezing employ sperm-rich ejaculate fractions (Pursel \& Johnson, 1975; Larrson \& Einarsson, 1975), thereby excluding much of the seminal plasma. Our previous studies showed that a basic protein fraction of seminal vesicle origin binds irreversibly to boar spermatozoa at ejaculation (Moore \& Hibbitt, 1976) and during cooling promotes sperm membrane disruption (Moore, Hall \& Hibbitt, 1976). We therefore tested the possibility that boar spermatozoa could be frozen more effectively in the absence of seminal vesicular fluid.

Spermatozoa from intact boars and from boars without seminal vesicles (Davies, Hall, Hibbitt \& Moore, 1975) were frozen in various diluents and comparisons were made of the sperm quality after thawing and the conception rates of gilts.

Whole ejaculates were collected from three intact boars and four boars without seminal vesicles (Large White breed), and spermatozoa were frozen to $-196^{\circ} \mathrm{C}$ by a method based on that of Pursel \& Johnson (1975). Previous tests with fresh semen inseminations had indicated that the fertility of all the boars was good. Semen samples exhibiting good progressive motility of spermatozoa at $37^{\circ} \mathrm{C}$ were transferred in a polythene bag to a $28^{\circ} \mathrm{C}$ water bath. Antibiotics (Streptopen: Glaxo Ltd; 1000 i.u. $/ \mathrm{ml}$ ) were added and the semen was cooled to $22^{\circ} \mathrm{C}$ over $2 \mathrm{~h}$. After centrifugation at $700 \mathrm{~g}$ for $15 \mathrm{~min}$, the spermatozoa were resuspended at a concentration of $1.2 \times 10^{9}$ cells $/ \mathrm{ml}$ in a buffer solution, $\mathrm{pH} 7.5$ (40 mM-Tes, $17 \mathrm{~mm}$-tris and $180 \mathrm{~mm}$-glucose) containing one of the following: (a) $20 \%$ (v/v) egg yolk; (b) $2 \%$ (w/v) casein; or (c) $2 \%$ (w/v) casein, 2.5 mM-phosphatidyl serine and $10 \mathrm{~mm}$ cholesterol. Aliquots $(5 \mathrm{ml})$ were cooled to $5^{\circ} \mathrm{C}$ at $6^{\circ} \mathrm{C} / \mathrm{h}$ and then diluted with an equal volume of the same diluent to which $2 \%(\mathrm{v} / \mathrm{v})$ glycerol had been added. These spermatozoa were immediately pellet frozen (in $0.2 \mathrm{ml}$ volumes) on solid $\mathrm{CO}_{2}$ (Nagase \& Niwa, 1964) and transferred to liquid nitrogen for storage (1-3 weeks).

Fifty semen pellets $(10 \mathrm{ml})$ were thawed by first placing them in a styrofoam box $(6 \times 20 \mathrm{~cm})$ for $3 \mathrm{~min}$ and they were then transferred to $50 \mathrm{ml}$ of IVT diluent (du Mesnil du Buisson \& Jondet, 1961) at $50^{\circ} \mathrm{C}$. Each sample was assessed for post-thaw motility at $37^{\circ} \mathrm{C}$. The percentage of eosinophilic (live/dead) spermatozoa was estimated from nigrosin-eosin smears examined the same day. Random samples were centrifuged and the supernatants assayed for L-aspartate 2-oxoglutarate aminotransferase (GOT) activity as described by Moore $e t$ al. (1976). Enzyme release was measured as a percentage of the total soluble enzyme activity of the cell. The latter was determined by homogenizing spermatozoa in IVT diluent, centrifuging at $10,000 \mathrm{~g}$ for $30 \mathrm{~min}$ and then assaying enzyme activity in the supernatant.

Gilts in oestrus were cervically inseminated with semen thawed within the previous $30 \mathrm{~min}$. Each gilt was inseminated 24 and $32 \mathrm{~h}$ after first standing to a boar and the reproductive tracts were examined 6 weeks later. Fetuses and corpora lutea were counted and the fetuses were examined superficially for abnormalities. The ovaries of non-pregnant gilts were inspected for cyclic activity.

\section{Results and discussion}

As shown in Table 1, for each diluent, spermatozoa from boars without seminal vesicles gave slightly higher conception rates than those from intact animals although these differences were not statistically significant. Overall conception rates were $35 \%$ for spermatozoa from boars without

* Present address: Cornell University Medical College, Dept. Obstetrics and Gynecology, 1300 York Avenue, New York, N.Y. 10021, U.S.A. 
Table 1. Details of pregnancies in gilts after insemination with frozen-thawed semen

\begin{tabular}{|c|c|c|c|c|}
\hline Diluent & Boars & $\begin{array}{l}\text { No. of gilts } \\
\text { pregnant/no. } \\
\text { inseminated }\end{array}$ & $\begin{array}{l}\text { Average fetal } \\
\text { litter size }\end{array}$ & $\begin{array}{l}\text { Average no. } \\
\text { of corpora lutea }\end{array}$ \\
\hline \multirow[t]{2}{*}{ (a) $20 \%$ egg yolk } & Intact & $4 / 12 \quad(36 \%)$ & $6 \cdot 5$ & $11 \cdot 1$ \\
\hline & Vesiculectomized & $5 / 12$ & $6 \cdot 8$ & $11 \cdot 6$ \\
\hline \multirow[t]{2}{*}{ (b) $2 \%$ casein } & Intact & $1 / 10$ & 8 & $12 \cdot 0$ \\
\hline & Vesiculectomized & $2 / 10$ & $8 \cdot 0$ & $11 \cdot 7$ \\
\hline $\begin{array}{l}\text { (c) } 2 \% \text { casein } \\
+ \text { cholesterol } \\
+ \text { phosphatidyl serine }\end{array}$ & $\begin{array}{c}\text { Intact } \\
\text { Vesiculectomized }\end{array}$ & $\begin{array}{ll}4 / 10 & \\
4 / 9 & (42 \%)\end{array}$ & $\begin{array}{l}8 \cdot 8 \\
8 \cdot 3\end{array}$ & $12 \cdot 1$ \\
\hline
\end{tabular}

* Significantly different $(P \leqslant 0.05)$ from the other diluents.

Values in parentheses indicate overall rate with that diluent.

vesicles and $29 \%$ for spermatozoa from intact boars. The diluents with $20 \%$ egg yolk (a) and $2 \%$ casein with cholesterol and phosphatidyl serine (c) provided significantly greater $(P \leqslant 0.05)$ cryoprotection than did that with $2 \%$ casein (b). However, the features used to evaluate sperm viability varied only slightly for the spermatozoa in the three diluents (Table 2). The least fertile samples of spermatozoa (from intact boars and frozen in $2 \%$ casein) released the highest levels of GOT and although they gave high post-thaw motility $(35-40 \%)$ they displayed the greatest proportion of cosinophilic ('dead') spermatozoa. In general, levels of enzyme release from the spermatozoa after thawing were three times those before freezing, indicating that substantial membrane damage had occurred in at least some spermatozoa during freezing and thawing, irrespective of the diluent composition.The conception rates with the egg yolk diluents were lower than those reported by Larsson \& Einarsson (1976) and Pursel \& Johnson (1975), perhaps because of breed differences or variations in the cooling, freezing and thawing procedures.

At ejaculation, seminal vesicular proteins bind to spermatozoa which subsequently become more susceptible to cold shock (Moore et al., 1976). It is not clear, however, what effect these proteins have on the spermatozoa during freezing and thawing. Crabo \& Hunter (1975) have suggested that sperm-coating proteins may enhance the fertility of frozen-thawed boar spermatozoa by preventing their early elimination from the female tract. Larsson \& Einarsson (1976) concluded that an important function of the thawing diluents (including seminal plasma and protein-free seminal plasma) was to preserve this 'protective' protein coating. Our results indicate that the presence or absence of seminal vesicular fluid at ejaculation has only a small effect on the fertilizing ability of spermatozoa frozen and thawed in suitable diluents. The contributions made by the prostatic secretions cannot be assessed, but it can be concluded that proteins from the seminal vesicles are not important for maintaining sperm fertility after freezing and thawing. From the results of previous experiments (Moore et al., 1976), it was hoped that the proportion of surviving spermatozoa from vesiculectomized boars would be greater at $5^{\circ} \mathrm{C}$ and that a greater number of cells capable of fertilization would therefore persist after freezing and thawing. These hopes were not realized: spermatozoa from boars without seminal vesicles gave conception rates which were not significantly different from those obtained using spermatozoa from intact boars, and the viability of the spermatozoa before and after freezing (as measured by the features shown in Table 2) was apparently the same for all the animals. The reason for this is unclear. The cryoprotective agents used in this study may have reduced the deleterious effects of the seminal vesicular proteins on spermatozoa from intact animals without enhancing the viability of spermatozoa from boars without seminal vesicles. The high levels of enzyme release and eosinophilic cells after thawing, although not an accurate indication of sperm fertilizing capacity (Linford, Glover, Bishop \& Stewart, 1976), suggest that for all treatments most spermatozoa were damaged during freezing and thawing, although the percentage motility was similar before and after freezing. 
Table 2. Enzyme release (GOT), motility, and eosinophilic cells of boar spermatozoa before freezing $\left(5^{\circ} \mathrm{C}\right)$ and after thawing

\begin{tabular}{|c|c|c|c|c|c|c|c|}
\hline \multirow[b]{2}{*}{ Diluent } & \multirow[b]{2}{*}{ Boar } & \multicolumn{2}{|c|}{ Enzyme release* } & \multicolumn{2}{|c|}{ Motility (\%) } & \multicolumn{2}{|c|}{$\begin{array}{l}\text { Eosinophilic } \\
\text { spermatozoa (\%) }\end{array}$} \\
\hline & & $5^{\circ} \mathrm{C}$ & $\begin{array}{l}\text { After } \\
\text { thawing }\end{array}$ & $5^{\circ} \mathrm{C}$ & $\begin{array}{l}\text { After } \\
\text { thawing }\end{array}$ & $5^{\circ} \mathrm{C}$ & $\begin{array}{l}\text { After } \\
\text { thawing }\end{array}$ \\
\hline $\begin{array}{l}\text { (a) } 20 \% \\
\text { egg yolk }\end{array}$ & $\begin{array}{l}\text { Intact } \\
\text { Vesicul- } \\
\text { ectomized }\end{array}$ & $\begin{array}{l}26(22-29) \\
25(23-28)\end{array}$ & $\begin{array}{l}82(73-94) \\
77(70-79)\end{array}$ & $\begin{array}{l}36(32-38) \\
30(28-31)\end{array}$ & $\begin{array}{l}30(25-32) \\
37(35-40)\end{array}$ & $\begin{array}{l}36(34-41) \\
35(29-42)\end{array}$ & $\begin{array}{l}71(64-81) \\
67(58-71)\end{array}$ \\
\hline (b) $2 \%$ casein & $\begin{array}{c}\text { Intact } \\
\text { Vesicul- } \\
\text { ectomized }\end{array}$ & $\begin{array}{l}33(28-37) \\
23(20-26)\end{array}$ & $\begin{array}{l}86(79-97) \\
73(68-83)\end{array}$ & $\begin{array}{l}31(24-33) \\
30(28-37)\end{array}$ & $\begin{array}{l}37(35-40) \\
26(25-29)\end{array}$ & $\begin{array}{l}38(36-39) \\
32(26-33)\end{array}$ & $\begin{array}{l}83(76-96) \\
72(66-75)\end{array}$ \\
\hline $\begin{array}{l}\text { (c) } 2 \% \text { casein } \\
+ \text { cholesterol } \\
\text { + phosphatidyl } \\
\text { serine }\end{array}$ & $\begin{array}{l}\text { Intact } \\
\text { Vesicul- } \\
\text { ectomized }\end{array}$ & $26(23-30)$ & $84(81-89)$ & $38(35-42)$ & $27(25-30)$ & $32(29-35)$ & $79(76-81)$ \\
\hline
\end{tabular}

Values are given as the mean of 4 samples and the range (in parentheses).

* As $\%$ of the total amount of sperm soluble enzyme ( 3.62 units $/ 10^{9}$ spermatozoa).

As expected, the diluent composition at freezing had a marked effect on sperm fertility. The addition of cholesterol and phosphatidyl serine greatly enhanced the cryoprotective effect of casein diluent. Butler \& Roberts (1975) have demonstrated that phosphatidyl serine protects boar spermatozoa specifically against the effects of rapid cooling, and preliminary experiments with various phospholipids and cholesterol in this laboratory (Moore, 1975) showed that a combination of phosphatidyl serine and cholesterol preserved the viability of boar spermatozoa cooled to $5^{\circ} \mathrm{C}$. The present work indicates that this cryoprotection continues during freezing and thawing to a level at least equal to that obtained with egg yolk. It is noteworthy that Pace \& Graham (1974) implicated a lipoprotein fraction of egg yolk as the active factor in protecting bovine spermatozoa during cooling.

One of us (H. D. M. M.) was in receipt of a studentship from the Meat and Livestock Commission for the duration of the study.

\section{References}

Butler, W.J. \& RoBerts, T.K. (1975) Effects of some phosphatidyl compounds on boar spermatozoa following cold shock or slow cooling. J. Reprod. Fert. 43, 183-187.

Crabo, B.G. \& Hunter, A.G. (1975) Sperm maturation and epididymal function. In Control of Male Fertility, pp. 2-23. Eds J. J. Sciarra, C. Markland \& J. J. Speidel. Harper and Row, New York.

Davies, D.C., Hall, G., Hibbitt, K.G. \& Moore, H.D.M. (1975) The removal of the seminal vesicles from the boar and the effects on the semen characteristics. J. Reprod. Fert. 43, 305-312.

DU Mesnil du Buisson, F. \& Jondet, R. (1961) Utilization du $\mathrm{CO}_{2}$ dans l'insemination porcine. Proc. 4th Int. Congr. Anim. Reprod. \& A. I., The Hague 4, 822-827.

Larsson, K. \& Einarsson, S. (1975) Fertility and postthawing characteristics of deep frozen boar spermatozoa. Andrologia 7, 25-30.
LARsson, K. \& EInARSSON, S. (1976) Fertility of deep frozen boar spermatozoa. Influence of thawing diluent and of boars. Acta vet. scand. 17, 43-62.

LASLEY, J.K. \& BOGART, R. (1944) A comparative study of epididymal and ejaculated spermatozoa of the boar. J. Anim. Sci. 3, 360-370.

Linford, E., Glover, F.A., Bishop, C. \& Stewart, D.L. (1976) The relationship between semen evaluation methods and fertility in the bull. J. Reprod. Fert. 47, 283-291.

MoORE, H.D.M. (1975) Some effects of seminal plasma on the long term preservation of boar spermatozoa. $\mathrm{Ph}$.D. thesis, Reading University.

Moore, H.D.M. \& HibitT, K.G. (1976) The binding of labelled basic proteins by boar spermatozoa. J. Reprod. Fert. 46, 71-76.

Moore, H.D.M., Hall, G.A. \& HibitT, K.G. (1976) Seminal plasma proteins and the reaction of spermatozoa from intact boars and from boars without 
seminal vesicles to cooling.J. Reprod. Fert. 47, 39-45. NAGASE, H. \& NiWA, T. (1964) Deep freezing bull semen in concentrated pellet form. I. Factors affecting survival of spermatozoa. Proc. 5th Int. Congr. Anim. Reprod. \& A. I., Trento 4, 410-415.

Pace, M.M. \& Graham, G.I. (1974) Components in egg yolk which protect bovine spermatozoa during freezing. J. Anim. Sci. 39, 1144-1149.
Pursel, V.G. \& Johnson, L.A. (1975) Freezing of boar spermatozoa. Fertilising capacity with concentrated semen and a new thawing procedure. J. Anim. Sci. 40, 99-102.

PuRsRl, V.G., JoHnson, L.A. \& RAMPACEK, G.B. (1972) Acrosome morphology of boar spermatozoa incubated before cold shock. J. Anim. Sci. 34, 278283.

Received 6 December 1976 